GLOBAL JOURNAL OF GEOLOGICAL SCIENCES VOL. 18, 2020: 1-14

COPYRIGHT@ BACHUDO SCIENCE CO. LTD PRINTED IN NIGERIA ISSN 1596-6798

www.globaljournalseries.com, Email: info@globaljournalseries.com

\title{
GEOCHEMISTRY AND PALEOENVIRONMENT OF THE PHOSPHORITES FROM THE AMEKI FORMATION, NIGER DELTA, NIGERIA
}

\author{
ONUIGBO, EVANGELINE NJIDEKA, OKORO, ANTHONY UWAOMA AND CHIBUZOR, STELLA 'NWAIFE'
}

(Received 1 April 2019; Revision Accepted 16 May 2019)

\begin{abstract}
The phosphorites of the Ameki Formation occur as nodules, pellets as well as primary phosphatic shales and siltstones. Geochemical analysis of the phosphate samples was carried out to determine its chemical composition as well as its depositional environment. The methodology applied include XRF, INAA, XRD and thin section petrography using Polarizing Microscope. The XRF result identified $\mathrm{CaO}-\mathrm{P}_{2} \mathrm{O}_{5^{-}} \mathrm{F}$ as the major mineral group, $\mathrm{SiO}_{2}, \mathrm{Al}_{2} \mathrm{O}_{3}, \mathrm{Fe}_{2} \mathrm{O}_{3}$, $\mathrm{MgO}$ and $\mathrm{TiO}_{2}$, which show minor occurrences and $\mathrm{Cr}, \mathrm{U}, \mathrm{Pb}, \mathrm{V}, \mathrm{Cu}, \mathrm{Zn}, \mathrm{Se}$ and $\mathrm{Cd}$ that occur in trace amounts. The nodules and pellets are of medium to high grade $\left(25-34 \mathrm{wt} \% \mathrm{P}_{2} \mathrm{O}_{5}\right)$ whereas the primary phosphatic shales and siltstones are of low to medium grade $\left(4.5-22 \mathrm{wt} \% \mathrm{P}_{2} \mathrm{O}_{5}\right)$. The phosphorites comprise mostly of francolites. The mean index of refraction estimated by Becke-line method using Standard Polarizing Microscope gave 1.634 and1.636.XRD analysis yielded an average values of9.243 $( \pm 0.002) A^{\circ}$ and $6.715( \pm 0.002) A^{\circ}$ for a and $c$ crystallographic axes respectively with an axial ratio (c/a) of 0.726 for unit cell parameter, suggestive of low degree of carbonate substitution. An increase in $\mathrm{P}_{2} \mathrm{O}_{5}$ content is found to be accompanied by increase in $\mathrm{CaO}, \mathrm{CO}_{2}$ and $\mathrm{F}$ contents, but by a decrease in $\mathrm{H}_{2} \mathrm{O}$, organic carbon, $\mathrm{SiO}_{2}$ and $\mathrm{Fe}$ contents indicative of amorphous solid phase of calcium phosphate. The phosphorite is interpreted to form under high biologic productive, shelf setting. High nutrient availability in the ancient sea is linked to upwelling along the West African Coastline during the Eocene.
\end{abstract}

KEYWORDS: Phosphorites; Geochemistry; Paleoenvironment; Ameki; Francolites; Nodules

\section{INTRODUCTION}

Sedimentary phosphorites are rocks that are significantly enriched in phosphorus over other types of rocks (Boggs, 2006). They contain 5 to $35 \% \mathrm{P}_{2} \mathrm{O}_{5}$ and can be called by a variety of other names such as phosphate rock, rock phosphate and phosphates (Boggs, 2006; Nichol, 2009). Phosphorites are of special economic interest although their total volume in the geologic record is small (Boggs, 2006). Phosphorites occur in the low- latitude upwelling zones on the western shelves and continental margins of North and South America, Africa and India, as well as off the east coast of Australia (Baturin et al., 1972; Parker and Andseisser, 1972; Veeh et al., 1973; Burnett et al., 1980; Sheldon, 1981). They were also found on the floor of the Atlantic, Pacific and Indian Oceans (Baturin. 1982) and are recorded on the present ocean floor at shallow depths in the vicinity of coastlines. However, the largest phosphorite- bearing regions are situated along the west coasts of Africa and America, the east coast of the USA, off New Zealand and in the central part of the Northern
Pacific (Baturin and Bezrukov, 1979). Formation of phosphate nodules in siliciclastic depositional systems is linked to upwelling, re- working and re- deposition (Föllmi, 1996; Tribovillard et al., 2006; Li et al., 2015). The process of phosphogenesis occur in two stages (Kolodny, 1980) viz; precipitation of apatite (CFA) or its metastable precursors by diagenetic process in a reducing basin by phosphorus mobilization in porewaters and re- working and enrichment of the diagenetically formed phosphorite grains by mechanical concentration processes (Cook, 1976; Glenn et al., 1994; Föllmi, 1996; Filipelli, 2011) under oxidizing conditions (Kolodny, 1980). The concentration is considered to take place under high energy hydrodynamic regime (Föllmi, 1996; Trappe, 1998; Li et al., 2015). The prime genetic process in the formation of diagenetic phosphorites however, is believed to be the replacement of carbonate by phosphate (Ames, 1959; Simpson, 1964).

Depositional environments of ancient phosphorites and phosphatic sediments have been reconstructed using

Onuigbo, Evangeline Njideka, Department of Geological Sciences, Nnamdi Azikiwe University, P.M.B. 5025, Awka, Nigeria.

Okoro, Anthony Uwaoma, Department of Geological Sciences, Nnamdi Azikiwe University, P.M.B. 5025, Awka, Nigeria.

Chibuzor, Stella 'Nwaife', Department of Geological Sciences, Nnamdi Azikiwe University, P.M.B. 5025, Awka, Nigeria. 
geochemical proxies (e.g., Galfati et al., 2010; Dumoulin et al., 2011; Khan et al., 2012; Dar and Khan, 2016; Garnit et al., 2017).

The Eocene Ameki Formation has been described asa clastic unit of about $1,550 \mathrm{~m}$ thick (Arua, 1982). Nwajide (2013) gave the maximum thickness of between 1,200 and $1,500 \mathrm{~m}$ for the formation. Lithologically, the formation is very heterogeneous and consists of alternating units of argillaceous, greenish- blue sandstones, clay stone, shale and white sandstone with thin limestone bands (Arua, 1982). The argillaceous sandstone member exposed along Umuahia- Bende road has been described as being highly distinctive in its micaceous and gypsiferous contents with chunks of amber, pockets of lignite and calcareous phosphatic nodules and bone beds. Carbonaceous and plant fragments are also common. Two distinct subfacies recognized include; the lower fine to coarse sandstones with intercalations of shale and thin shelly (often coquinoid) limestone and the upper coarse, planar cross bedded sandstones, bands of fine, grey- green sandstone, and sandy clay (Nwajide, 2013).

Several workers have interpreted the environment of deposition based on its diverse and richly abundant assemblages of micro and macrofossils (Adegoke, 1969; Adegoke and Tevesz, 1974; Arua, 1982, 1988; Fayose and Ola, 1990; Nzekwe and Okoro, 2016). The paleoenvironment was variously interpreted as estuarine (White, 1926), shallow marine (Adegoke and Tevesz, 1974; Nzekwe and Okoro, 2016) and inshore sandy environment (Arua, 1982). Nwajide (2013) suggested the environment of deposition to be shallow marine with the presence of amber and lignite suggesting shallowing that marked establishment of swampy and in coaling conditions. The paleoenvironment of the phosphatic rocks of the Ameki Formation needs to be interpreted using the geochemical proxies.

The age of the Ameki Formation has been interpreted as Eocene (Berggren, 1960; Adegoke, 1969; Adegoke et al., 1980; Whiteman, 1982; Fayose and Ola, 1990).

This paper is aimed at determination of the chemical composition of the phosphatic rocks of the Ameki Formation, interpretation of its depositional environment and mode of formation of the phosphorites using geochemical proxies. Figure 1 is the geologic map of the study area.

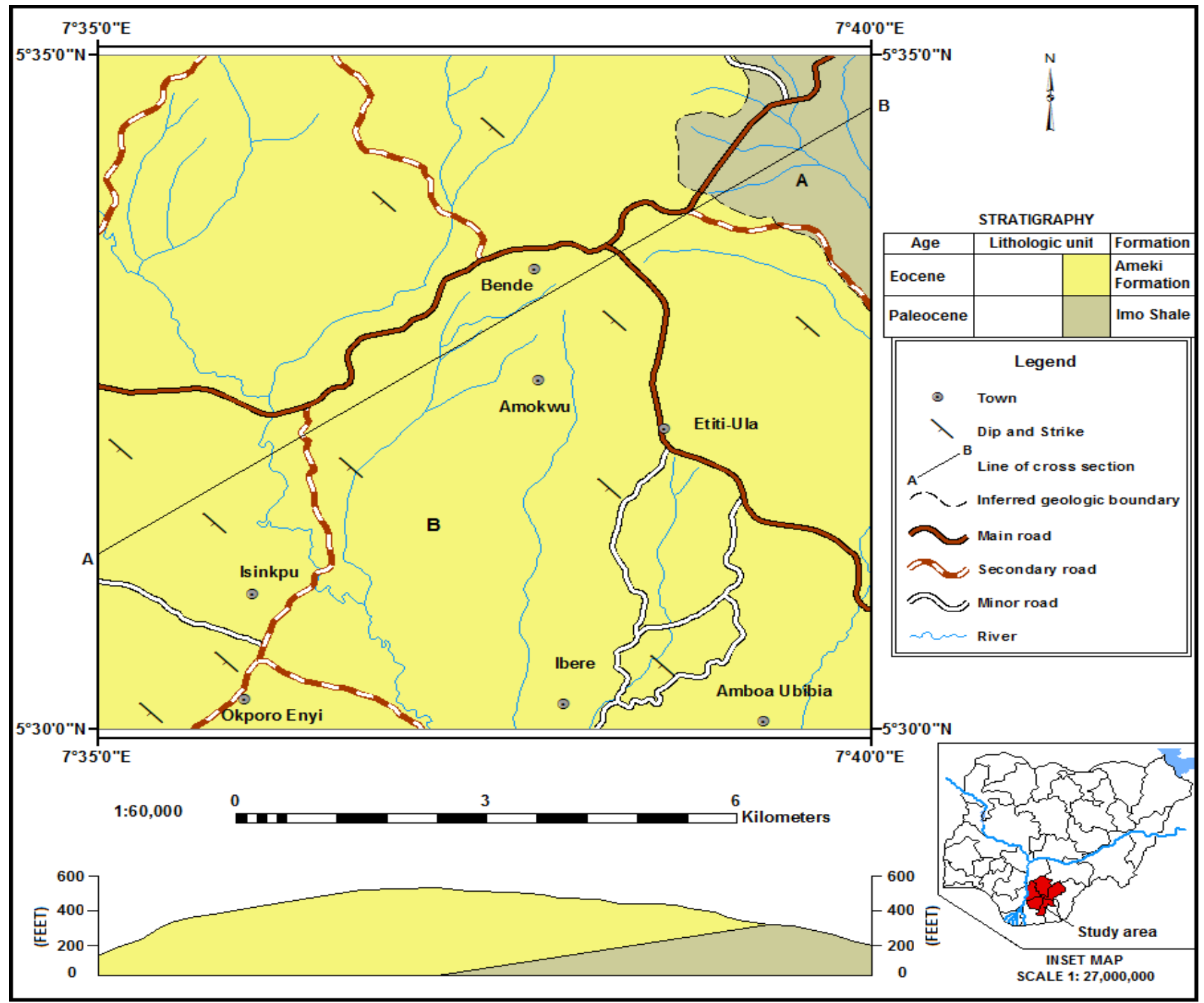

Fig. 1: Geologic map of the study area 


\section{REGIONAL TECTONICS AND STRATIGRAPHIC SETTING}

The evolution of the Niger Delta Basin is related to the opening of the southern Atlantic Ocean during the break- up of Gondwana Supercontinent and installation of the Benue Trough in the early Cretaceous (Burke et al., 1972; Benkhelil. 1982, 1989; Hoque and Nwajide, 1984; Fairhead, 1988). The Benue Trough is a rift within the West and Central African Rift System and represents a major tectonic structure in the Nigerian sedimentation history. The trough after its development, was filled with both continental and marine sediments ranging in age from early Cretaceous to Santonian in its southern part (Table 1). The Santonian thermotectonics event later folded and uplifted the sediments in the Southern Benue Trough into the Abakaliki- Benue Anticlinorium (Murat, 1972) and there was translocation of the depositional axis which involved a simultaneous subsidence of the Anambra Basin and the Afikpo SubBasins to the northwest and southeast of the folded axis respectively (Murat, 1972; Burke, 1972; Burke et al., 1972; Benkhelil, 1989). The Anambra Basin after its evolution was filled from late Campanian to Danian with the sediments of the Nkporo Group, Mamu, Ajali and Nsukka Formations which conformably and successively overlie each other. Establishment of the Niger Delta occurred due to further subsidence of the Southern Benue Trough after the Anambra Basin was filled and sediments compacted. This subsidence induced the major marine transgression of the early Paleocene and thus sedimentation began in the Niger Delta basin.

The Imo Formation which is the basal outcropping lithostratigraphic unit of the Niger Delta was deposited during the late Paleocene transgression. The formation is conformably and successively overlain by the Ameki Group (middle to late Eocene) and Ogwashi-Asaba and Benin Formations. The Ameki Formation was deposited north of the Niger Delta and south of Anambra Basin (Short and Stauble, 1967).

Though the Southern Benue Trough, the Anambra Basin and the Niger Delta Basin are vertically stacked in the southern reaches (Table 1), they are separate stratigraphic entities (Nwajide, 2013).

Table 1: Stratigraphic succession in the southern Benue Trough, Anambra Basin and Niger Delta (from Reyment, 1965; Short and Stauble, 1967; Maron, 1969, Murat, 1972; Whiteman, 1982; Nwajide, 2013)

\begin{tabular}{|c|c|c|c|c|c|c|c|}
\hline \begin{tabular}{l|l} 
TIME SCALE \\
& Quaternary
\end{tabular} & \multicolumn{2}{|c|}{ SCALE } & \multicolumn{5}{|c|}{ SEDIMENTARY UNITS } \\
\hline \multirow{7}{*}{$\begin{array}{l}\text { 응 } \\
\text { 잉 } \\
0\end{array}$} & \multicolumn{2}{|c|}{ Quaternary } & \\
\hline & \multicolumn{2}{|c|}{ Pliocene } & & & & & \\
\hline & \multicolumn{2}{|l|}{ Miocene } & & & & & \\
\hline & \multicolumn{2}{|c|}{ Oligocene } & \multirow{3}{*}{ 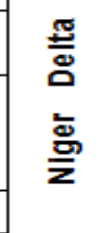 } & \multicolumn{4}{|c|}{ Ogwashi-Asaba Formation } \\
\hline & \multicolumn{2}{|l|}{ Eocene } & & \multicolumn{2}{|c|}{ Nanka Formation } & \multicolumn{2}{|c|}{$\begin{array}{l}\text { Ameki } \\
\text { Formation }\end{array}$} \\
\hline & \multirow{2}{*}{ Paleocene } & Thanetian & & \multicolumn{4}{|c|}{ Imo Formation } \\
\hline & & Danian & \multirow{4}{*}{ 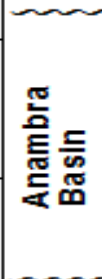 } & \multicolumn{4}{|c|}{ Nsukka Formation } \\
\hline \multirow{3}{*}{ 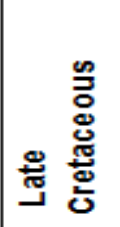 } & \multirow{2}{*}{\multicolumn{2}{|c|}{ Maastrichtian }} & & Ajal & Formation & & \\
\hline & & & & Man & Iu Formatic & & \\
\hline & \multicolumn{2}{|c|}{ Campanian } & & Nkporo Fm & Enugu $\mathrm{Fm}$ & $\begin{array}{c}\text { Afikpo } \\
\text { Sst }\end{array}$ & $\begin{array}{c}\text { Otobi } \\
\text { Sst }\end{array}$ \\
\hline & \multicolumn{2}{|c|}{ Santonian } & & \multicolumn{4}{|c|}{ Unconformity } \\
\hline & \multicolumn{2}{|c|}{ Coniacian } & & \multicolumn{4}{|c|}{ Awgu Formation } \\
\hline & \multicolumn{2}{|c|}{ Turonian } & & \multicolumn{4}{|c|}{ Ezeaku G roup } \\
\hline & \multicolumn{2}{|c|}{ Cenomanian } & & \multicolumn{4}{|c|}{ Mfamosing Limestone } \\
\hline 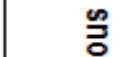 & \multicolumn{2}{|l|}{ Albian } & & \multicolumn{4}{|c|}{ Abakaliki Formation } \\
\hline 츤 总 & \multicolumn{2}{|l|}{ Aptian } & & \multicolumn{4}{|c|}{ Awi Formation } \\
\hline ш 0 & \multicolumn{2}{|c|}{ Preaptian } & & $?$ & $?$ & ? & \\
\hline & Preca & & & Base & ment Com & olex & \\
\hline
\end{tabular}




\section{MATERIALS AND METHODS}

Ten selected fresh samples of nodules, pellets and phosphatic shales and siltstones were collected from the outcrop sections of the Ameki Formation exposed at Bende-Ameke area in southeastern Nigeria for laboratory analyses. The samples were carefully labelled to avoid mix up.

Geochemical analysis for major and trace elements was done using Standard X- Ray Fluorescence Spectrometry (XRF) technique. Each of the dried samples was crushed to powdered form (200 mesh size) using an agate mortar. Major element composition and trace elements such as $\mathrm{Zn}, \mathrm{Cu}, \mathrm{V}, \mathrm{U}$ and $\mathrm{Cr}$ were determined by $X$ - Ray Fluorescence (XRF) in fused $\mathrm{LiBO}_{2} / \mathrm{Li}_{2} \mathrm{~B}_{4} \mathrm{O}_{7}$ (lithium metaborate/lithium tetraborate) disc using a Siemens SRS- 3000 wavelength- dispersive X- Ray Fluorescence Spectrometer with Rh- anode X- Ray tube as a radiation source. Other trace elements were checked for using Instrumental Neutron Activation Analysis (INAA). Wet chemical methods were used to determine $\mathrm{CO}_{2}$ and $\mathrm{F}$ contents while weight loss methods were used to determine loss of water content $\left(\mathrm{H}_{2} \mathrm{O}^{-}\right)\left(\right.$at $120^{\circ} \mathrm{C}$ ), and the loss on fusion (with lithium borate flux) at $1000^{\circ} \mathrm{C}$.
The unit cell parameter was determined by $X$-Ray Diffraction (XRD) using Electric XRD- 5 Diffractometer with CuKa radiation.

The refractive index of four selected samples were also estimated by the becke-line method using Standard Polarizing Microscope.

Concentrations of $\mathrm{P}, \mathrm{Fe}$ (III), $\mathrm{Al}, \mathrm{Ca}$ and $\mathrm{Ba}$ were recalculated from their oxides using the molar weight method and the degree of pyritization (DOP) was estimated based on Raiswell et al. (1988). The results of the major and trace elements distributions, unit cell parameters and index of refraction formed the basis for the interpretations.

\section{RESULT}

The phosphorites were collected in the field as nodules, pellets, primary phosphatic shales and siltstones. The result of XRF analysis is shown in Table 2. CaO has the highest concentration among the major oxides followed by $\mathrm{P}_{2} \mathrm{O}_{5}$. Concentrations of $\mathrm{Na}_{2} \mathrm{O}, \mathrm{K}_{2} \mathrm{O}, \mathrm{BaO}, \mathrm{S}, \mathrm{Cl}$ and $\mathrm{H}_{2} \mathrm{O}$ is less than $1 \mathrm{wt} \%$ (Table 2a). For the trace elements, concentration in decreasing order of abundance in the phosphorites is as follow; $\mathrm{Cr}, \mathrm{U}, \mathrm{Pb}, \mathrm{V}$, $\mathrm{Cu}, \mathrm{Zn}, \mathrm{Se}$, Cd (Table 2b). Ranges of concentrations of the re- calculated major elements are shown in Table $2 c$.

Table 2a: Ranges of major elements, oxides and organic matter in the phosphorites of the Ameki Formation

\begin{tabular}{|l|l|}
\hline Constituents & Concentration (wt\%) \\
\hline $\mathrm{P}_{2} \mathrm{O}_{5}$ & $\begin{array}{l}25.00-34.00 \text { in nodules } \\
4.50-22.00 \text { in phosphatic shales } \\
\text { and siltstones }\end{array}$ \\
\hline $\mathrm{Fe}$ & $3.40-8.00$ \\
\hline $\mathrm{Fe}_{2} \mathrm{O}_{3}$ & $1.25-4.80$ \\
\hline $\mathrm{Al}_{2} \mathrm{O}_{3}$ & $1.60-3.80$ \\
\hline $\mathrm{Cl}$ & $0.02-0.06$ \\
\hline $\mathrm{MgO}$ & $0.95-2.05$ \\
\hline $\mathrm{CaO}$ & $49.00-56.00$ \\
\hline $\mathrm{S}$ & $0.01-0.04$ \\
\hline $\mathrm{SiO}$ & $3.00-5.50$ \\
\hline $\mathrm{BaO}$ & $0.12-0.14$ \\
\hline $\mathrm{Na}_{2} \mathrm{O}$ & $0.13-0.16$ \\
\hline $\mathrm{K}_{2} \mathrm{O}$ & $0.31-0.66$ \\
\hline $\mathrm{Ti}$ & $1.0-$ \\
\hline $\mathrm{H}_{2} \mathrm{O}$ & $0.35-0.68$ \\
\hline $\mathrm{CO}$ & $1.86-3.25$ \\
\hline $\mathrm{F}$ & $2.30-4.80$ \\
\hline $\mathrm{MnO}$ & $0.02-0.08$ \\
\hline $\mathrm{Mn}$ & $2.00-8.00$ \\
\hline Organic matter & Nil- 6.00 \\
\hline
\end{tabular}


Table 2b: Trace elements in the phosphorites of the Ameki Formation

\begin{tabular}{|l|l|}
\hline Element & $\begin{array}{l}\text { Concentration } \\
\text { (ppm) }\end{array}$ \\
\hline $\mathrm{Zn}$ & $3.00-5.00$ \\
\hline $\mathrm{Cu}$ & $2.00-10.00$ \\
\hline $\mathrm{V}$ & Nil- 30.00 \\
\hline $\mathrm{Hg}$ & Nil- trace \\
\hline $\mathrm{Pb}$ & $2.00-38.00$ \\
\hline $\mathrm{Se}$ & Nil- 5.00 \\
\hline $\mathrm{Cr}$ & Nil- 60.00 \\
\hline $\mathrm{As}$ & Not detected \\
\hline $\mathrm{Cd}$ & Nil- 2.60 \\
\hline $\mathrm{U}$ & Nil- 50.00 \\
\hline
\end{tabular}

Table 2c: Ranges of concentrations of the re- calculated major elements

\begin{tabular}{|l|l|}
\hline Element & Concentration $(\mathrm{wt} \%)$ \\
\hline $\mathrm{Fe}(\mathrm{III})$ & $0.87-3.36$ \\
\hline $\mathrm{Ca}$ & $35.02-40.08$ \\
\hline $\mathrm{Al}$ & $0.85-2.01$ \\
\hline $\mathrm{P}$ & $1.96-14.84$ \\
\hline $\mathrm{Ba}$ & $0.11-0.13$ \\
\hline
\end{tabular}

The nodules and the pellets are of medium to high grades $\left(25-34 \mathrm{wt} \% \quad \mathrm{P}_{2} \mathrm{O}_{5}\right)$ whereas the primary phosphatic shales and siltstones are of low to medium grades ( 4.5 and $22 \mathrm{wt} \% \mathrm{P}_{2} \mathrm{O}_{5}$ ). The major mineral in the phosphorites is the Carbonate hydroxyl fluorapatites, consisting of $\mathrm{CaO}, \mathrm{P}_{2} \mathrm{O}_{5}$ and $\mathrm{F}$, and are referred to as francolites. Francolites have been described as the principal mineral in sedimentary phosphorites which exhibit several systematic isomorphous substitutions. These substitutions result in measurable variations of the crystallographic properties including unit- cell parameters (McClellan, 1980). The variability in chemical composition can be represented by $(\mathrm{Ca}, \mathrm{Mg}$, $\mathrm{Sr}, \mathrm{Na})_{10}\left(\mathrm{PO}_{4}, \mathrm{SO}_{4}{ }^{2-}, \mathrm{CO}_{3}{ }^{-}\right)_{6} \mathrm{~F}_{2-3}$ (Benmore et al., 1983).

The mean index of refraction $\left(n_{\varepsilon}\right.$ and $\left.n_{\omega}\right)$ measured for the selected samples gave values of1.634 and 1.636 respectively. Carbonate fluorapatite have been documented to have the refractive index (n) which ranges from1.614 to 1.633 for $n_{\varepsilon}$ and 1.622 to 1.640 forn $_{\omega}$ (Hand book of mineralogy, 2001- 2005 data publishing version 1).XRD analysis carried out on selected samples gave the values of $9.243( \pm 0.002) A^{\circ}$ and $6.715( \pm 0.002) A^{\circ}$ for $a$ and $c$ crystallographic axes respectively with an axial ratio (c/a) of 0.726 for unit cell parameters. The values are also not far from that of fluorapatite given as $\mathrm{a}=9.36 \mathrm{~A}^{\circ}, \mathrm{c}=6.88 \mathrm{~A}^{\circ}$, and $\mathrm{c} / \mathrm{a}=$ 0.7350 (Gruner et al., 1937). This reflects the hexagonal crystal system $\left(a=9.34 \mathrm{~A}^{\circ}, c=6.88 \mathrm{~A}^{\circ}\right.$ and $\left.\mathrm{a} / \mathrm{c}=0.737\right)$ and thus suggests a low degree of carbonate substitution by phosphates.
$\mathrm{SiO}_{2}, \mathrm{Al}_{2} \mathrm{O}_{3}, \mathrm{Fe}_{2} \mathrm{O}_{3}, \mathrm{MgO}$ and $\mathrm{TiO}_{2}$ are minimal. Millisite and Wavellite, which have been referred to as the principal aluminum phosphate minerals occur in small quantities and constitute the accessory minerals. Goethite which is also present is associated with the primary phosphates whereas quartz is the only crystalline gangue which was identified.

The result of XRF analysis also revealed that the primary phosphatic shales and siltstones which have the $\mathrm{P}_{2} \mathrm{O}_{5}$ value ranges of between 4.5 and $22 \mathrm{wt} \%$ contain between 49 and $50 \mathrm{wt} \% \mathrm{CaO}, 1.86$ and $2.5 \mathrm{wt} \% \mathrm{CO}_{2}$ and 2.3 and $2.5 w t \% F$. On the other hand, nodules which have the $\mathrm{P}_{2} \mathrm{O}_{5}$ value up to $34 \mathrm{wt} \%$ contain between 50 and $56 w t \% \mathrm{CaO}, 2.6$ and $3.25 \mathrm{wt} \% \mathrm{CO}_{2}$ and 3.2 and $4.8 \mathrm{wt} \% \mathrm{~F}$ (Table 3). These suggest the amount of $\mathrm{P}_{2} \mathrm{O}_{5}$ in the phosphorites to increase with increasing proportions of $\mathrm{CaO}, \mathrm{CO}_{2}$ and $\mathrm{F}$. This is in agreement with the strong positive correlations which exist between them (Figs. 3ac).

Furthermore, the values of $\mathrm{H}_{2} \mathrm{O}, \mathrm{SiO}_{2}, \mathrm{Fe}$ and organic matter contents in the nodules are between 0.35 and $0.38 w t \%, 3$ and $3.5 w t \%, 3.4$ and $4 w t \%$ and 0 and $0.95 \mathrm{wt} \%$ respectively, but in the primary phosphatic shales and siltstones, their values range from 0.48 to $0.62 w t \%$, 4to $5.5 w t \%, 5$ to $8 w t \%$ and 3.2 to $6 w t \%$, respectively (Table 3 ). This suggests decrease in their proportions with increasing $\mathrm{P}_{2} \mathrm{O}_{5}$ which is in agreement with the strong negative correlations which exist between them (Figs. 3d- $\mathrm{g}$ ). 
Table 3: Relationships between the proportions of $\mathrm{P}_{2} \mathrm{O}_{5}$ and other constituents of the phosphorites

\begin{tabular}{|l|l|l|}
\hline Constituents & $\begin{array}{l}\text { Nodules composition } \\
(\mathrm{wt} \%)\end{array}$ & $\begin{array}{l}\text { Primary phosphates (shales and } \\
\text { siltstones composition (wt\%) }\end{array}$ \\
\hline $\mathrm{P}_{2} \mathrm{O}_{5}$ & 34.00 & $4.50-22.00$ \\
\hline $\mathrm{CaO}$ & $50.00-56.00$ & $49.00-50.00$ \\
\hline $\mathrm{CO}_{2}$ & $2.60-3.25$ & $1.86-2.50$ \\
\hline $\mathrm{F}$ & $3.20-4.80$ & $2.30-2.50$ \\
\hline $\mathrm{H}_{2} \mathrm{O}$ & $0.35-0.38$ & $0.48-0.62$ \\
\hline $\mathrm{SiO}_{2}$ & $3.00-3.50$ & $4.00-5.50$ \\
\hline $\mathrm{Fe}$ & $3.40-4.00$ & $5.00-8.00$ \\
\hline Organic matter & Nil- 0.95 & $3.20-6.00$ \\
\hline
\end{tabular}

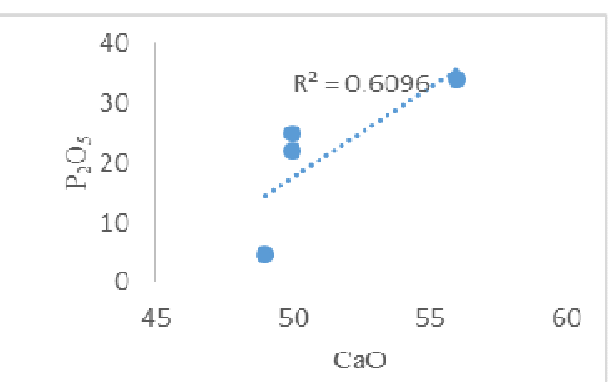

A

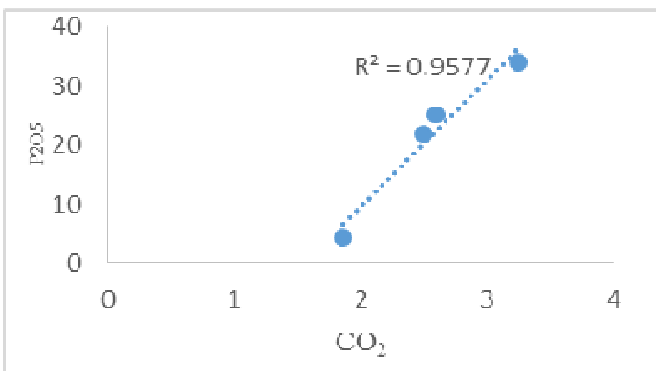

B

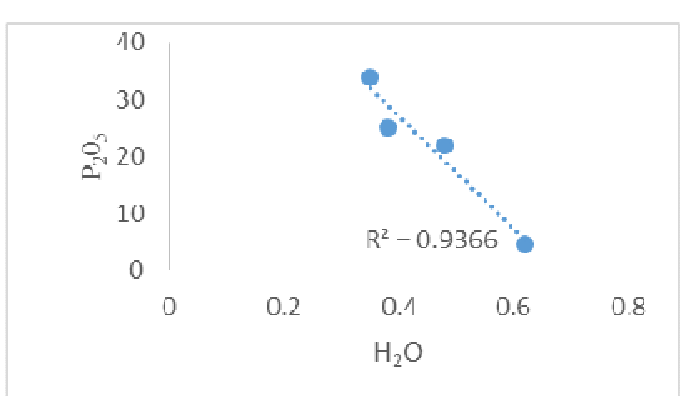

D

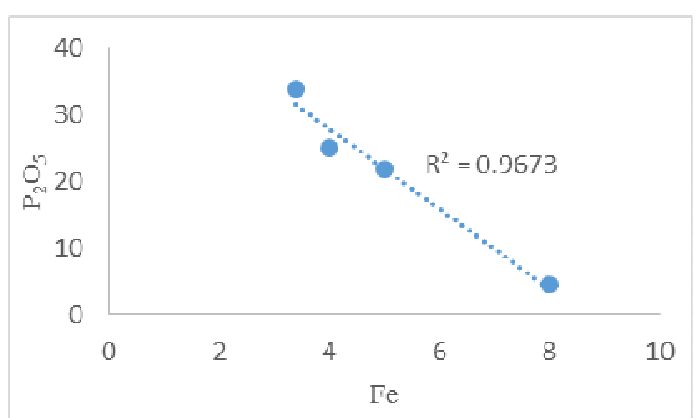

F

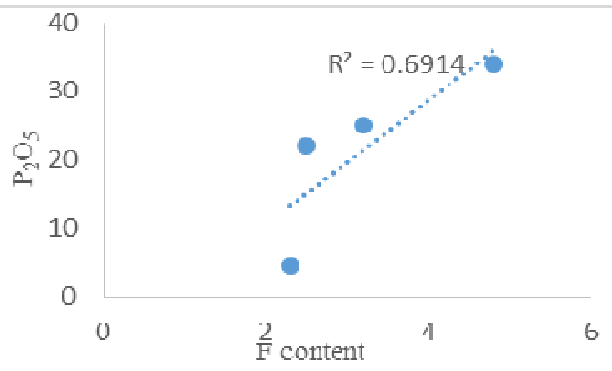

(



$\mathbf{E}$

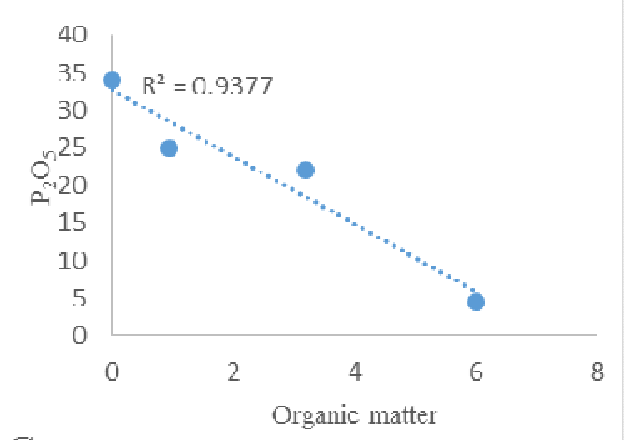

G

Fig 2: Relationships between $\mathrm{P}_{2} \mathrm{O}_{5}$ and (a) $\mathrm{CaO}$ (b) $\mathrm{CO}_{2}$ (c) F (d) $\mathrm{H}_{2} \mathrm{O}$ (e) $\mathrm{SiO}_{2}$ (f) $\mathrm{Fe}$ (g) Organic matter 


\section{DISCUSSION}

Sedimentary phosphorites are composed of calcium phosphate minerals, which are varieties of apatite with the principal types consisting of fluorapatite (CFA), given as $\left[\mathrm{Ca}_{5}\left(\mathrm{PO}_{4}\right) \mathrm{F}\right]$ typically in cryptocrystalline masses (grain sizes $<1 \mu \mathrm{m}$ ) and are referred to as cellophane, the chlorapatite $\left[\mathrm{Ca}_{5}\left(\mathrm{PO}_{4}\right) \mathrm{Cl}\right]$, and the hydroxyapatite $\left[\mathrm{Ca}_{5}\left(\mathrm{PO}_{4}\right)_{3} \mathrm{OH}\right]$ (Glenn et al., 1994; Boggs, 2006). The fluorapatites have been reported as originating from hydrothermal veins (Glenn et al., 1994) and hydroxyapatite from vertebrate bones and teeth. Most phosphorites are said to be carbonate hydroxyl fluorapatites in which up to $10 \%$ of the carbonate ions can be substituted for phosphate ions in order to yield the general formula $\mathrm{Ca}_{10} \quad\left(\mathrm{PO}_{4} \cdot \mathrm{CO}_{3}\right)_{6} \mathrm{~F}_{2-3}$ and are commonly called francolites. Detrital quartz, authigenicchert, opal- CT, calcite and dolomite are other common constituents of many phosphorites (Boggs, 2006). Clay minerals such as glauconite, illite, montmorillonite, and zeolite may also be present in some phosphorite deposits. Moderate abundance of organic matter is a characteristic of many phosphorites (Nathan, 1984).

Geochemistry of the phosphorites of the Ameki Formation studied are similar to that reported for South West Africa (Parker, 1971; Parker and Siesser, 1972; Dingle, 1975) and Midcontinent, USA (Ece, 1990). However, the $\mathrm{P}_{2} \mathrm{O}_{5}$ contents of the nodules from the Ameki Formation appears to be higher than that of phosphorites from South West Africa. The silica concentration is higher in the phosphorites of both South West Africa and Midcontinent, USA. Cronan (1980) observed that $P$ values increase with lithification in South West Africa. The $\mathrm{P}_{2} \mathrm{O}_{5}$ content reaches $8 \%$ or more in the lumps of phosphatized mud, $25 \%$ in unconsolidated nodules, $27-29 \%$ in brittle fine grained nodules and $31-33 \%$ in compact concretions. Higher value of some constituents such as $\mathrm{CaO}$ (49- $56 \mathrm{wt} \%$ ) was recorded in the phosphorites of the Ameki Formation. The maximum value for $\mathrm{SiO}_{2}$ in the phosphorites of the Ameki Formation is $5.5 \mathrm{wt} \%$ which is quite low compared to that of South West Africa and Midcontinent, USA. Variations in the average wholerock geochemical composition of phosphatic materials has been attributed to varying degree of dilution of the phosphatic materials by non-phosphatic components (Burnett, 1977; Birch, 1990). The minimal concentrations of $\mathrm{SiO}_{2}, \mathrm{~K}_{2} \mathrm{O}$ and $\mathrm{Fe}_{2} \mathrm{O}_{3}$ in the phosphorites of the Ameki compared to that of South West Africa suggest lower quartz and glauconite contents in the deposit. Ameki Phosphorites also recorded an increase in $\mathrm{CaO}, \mathrm{CO}_{2}$ and $\mathrm{F}$ with increasing $\mathrm{P}_{2} \mathrm{O}_{5}$ whereas $\mathrm{H}_{2} \mathrm{O}, \mathrm{SiO}_{2}, \mathrm{Fe}$ and organic matter concentrations decreased with increasing $\mathrm{P}_{2} \mathrm{O}_{5}$. This situation is suggestive of amorphous solid phase of calcium phosphate (Baturin, 1971; Robert and Vercoutere, 1986). The strong positive correlations between $\mathrm{P}_{2} \mathrm{O}_{5}$ and $\mathrm{CaO}, \mathrm{P}_{2} \mathrm{O}_{5}$ and $\mathrm{CO}_{2}$ as well as $\mathrm{P}_{2} \mathrm{O}_{5}$ and $\mathrm{F}$ (Figs. 3a- $\mathrm{c}$ ) indicate association in the crystal structure of the francolites whereas, the strong negative correlations which exist between $\mathrm{P}_{2} \mathrm{O}_{5}$ and $\mathrm{SiO}_{2}, \mathrm{P}_{2} \mathrm{O}_{5}$ and $\mathrm{H}_{2} \mathrm{O}, \mathrm{P}_{2} \mathrm{O}_{5}$ and $\mathrm{Fe}$ as well as $\mathrm{P}_{2} \mathrm{O}_{5}$ and organic matter show association with alumnosilicate group. Chen et al. (1996) outlined the sources of terrigenous alumnosilicates (clay minerals and fine grained rock- forming minerals)in the marine environment to include; discharge from the atmosphere in the form of air bone dusts and rivers as suspended matter.

\section{DEPOSITIONAL ENVIRONMENT \\ Paleo-redox Condition}

Trace element abundances in sediments and sedimentary rocks are very important tool in the reconstruction of paleodepositional conditions (Lyons et al., 2003; Algeo, 2004; Tribovillard et al., 2006). The response of some of the trace elements/metals such as $\mathrm{V}, \mathrm{Mo}, \mathrm{Cr}$, Co and $\mathrm{U}$ to redox variations (i.e under oxic and anoxic conditions) in the ambient sea has been employed as useful parameters in the reconstruction of the redox conditions in both recent and ancient sedimentary basins, especially in relationship to extensive organic matter deposition and sulfide formation in $\mathrm{O}_{2}$ - depleted environment (e.g Jones and Manning, 1994; Algeo and Magnard, 2004; Tribovillard et al., 2006; Rimmer, 2004; Rimmer et al., 2004; Nameroff et al., 2004; Pattan and Pearce, 2009). The $\mathrm{V} / \mathrm{Cr}$ and $\mathrm{Ni} / \mathrm{Co}$ ratios are very useful paleoredox tools also (Hatch and Leventhal, 1992; Jones et al., 1994; Morford and Emerson, 1999; Tribovillard et al., 2006; Pattan and Pearce, 2009; Yao et al., 2017). The threshold value for the Mo content of terrigenous detrital matter is 1 ppm (Dean et al., 1997) and 10 ppm for black shale (Vine and Tourtelot, 1970). Rare occurrence of $\mathrm{Mo}, \mathrm{Co}$ and $\mathrm{Ni}$ with depletion of $\mathrm{V}$ and $\mathrm{Cr}$ (0-30 ppm and $0-60 \mathrm{ppm}$ respectively) compared to the threshold for black shale (Vine and Tourtelot, 1970) are typical attribute of the Ameki Formation. These are suggestive of deposition under oxic condition. Scott and Lyons (2012) noted the adsorption of Mo to Mn- oxides and little Mo enrichment below sediment- water interface in a fully oxic condition. Also $\mathrm{Mn}$ is an element generally depleted under anoxic conditions, whereas elements such as $\mathrm{Cu}, \mathrm{Ni}, \mathrm{Mo}, \mathrm{V}, \mathrm{Zn}$ and $\mathrm{Cd}$ are enriched due to formation of organometallic complexes of sulfide minerals (Calvert and Pedersen, 1993; Tribolvillard et al., 2006; Wignall et al., 2007; Zhou et al., 2012). Mnvalue ranges of 2- $8 \mathrm{wt} \%$, depletion of $\mathrm{Zn}, \mathrm{Cu}$ and $\mathrm{Cd}$ and complete absence of $\mathrm{Mo}$ and $\mathrm{Ni}$ in the Ameki Formation is in agreement with an oxygenated water condition. Minor enrichment of $U$ has also been reported for oxic-suboxic environments (Yao et al., 2017). Based on the redox classification of the depositional environment of Jones and Manning (1994), V/Cr ratio of $<2$ and $\mathrm{Ni} / \mathrm{Co}$ ratio of $<5$ suggest oxic conditions. The average $\mathrm{V} / \mathrm{Cr}$ ratio for the Ameki Formation is 0.48 whereas $\mathrm{Ni}$ and $\mathrm{Co}$ are lacking. These are also in agreement with oxygenated water condition. However, Neubert et al. (2008) is of the opinion that $\mathrm{V} / \mathrm{Cr}$ ratio as well as $U$ and $V$ enrichment could not be used as indicators of depositional conditions in phosphatic rocks owing to the disturbances of the system by the substitutions of $\mathrm{V}$ and $\mathrm{U}$ into apatite.

\section{DEGREE OF PYRITIZATION (DOP)}

The intensity of pyrite formation in a sedimentary rock is an important paleoenvironmental tool which needs to be integrated with other environmental parameters (Taylor and Maquaker, 2011). DOP is defined as the ratio of pyrite- bound Fe (II) to pyrite- bound Fe (II) plus $\mathrm{HCl}$ extractable Fe (III) (Raiswell et al., 1988). Values of DOP close to 1 indicates that nearly all of the originally deposited reducible $\mathrm{Fe}$ (III) is now in the form of Fe (II) 
in pyrite, and are regarded as indicating the presence of euxinic conditions in which abundant sulfide was available (Lysons and Severman, 2006; Taylor and Macquaker, 2011). DOP values that are less than 0.8 indicate the availability of sulfide as the limiting factor controlling pyrite formation and thus suggestive of normal open- marine conditions. It is worth noting that DOP should be employed alongside other indicators because a high DOP value close to 1 may not always indicate oxygen- free conditions (Schieber, 2009). The calculated DOP for the Ameki Formation varies from $0.70-0.80$ with sulfur contents of between 0.01 and 0.04 wt $\%$. The paleoenvironment is interpreted as normalopen marine. The interpretation is in line with Arua (1988) that proposed normal to near normal marine for the Ameki Formation. Taylor and Maquaker (2011) summarized the processes which occur in three contrasting shallow- marine settings as follow; firstly, a situation where the reduction of detrital iron oxides is coupled to, or takes place in pore- waters that contain high concentrations of sulfide generated by sulfate reduction. This type of condition is obtainable in a shallow marine shelf sediment. Secondly, the case where abundant iron oxides susceptible to bacterial iron reduction are available, but the sulfide contents in the pore-water is low. Thirdly, system starved of reducible Fe (III) but containing abundant, dissolved reducedsulfur species. Canfield (1989) noted that when iron oxides are present in relatively high concentrations, dissolved sulfide is nearly absent from sediment pore waters (with concomitant high concentrations of dissolved $\mathrm{Fe}$ ), even in the presence of active sulfide production by sulfate reduction. A combination of experimental result and diagenetic modelling have shown that bacterial reduction of $\mathrm{Fe}$ oxides may be the source of pore-water Fe, and greater amounts of Fe are reduced by reaction of sulfides with iron oxides (Canfield, 1989). It is important to note that the concentration of $\mathrm{Fe}$ (III) in sediments is important but, its bioavailability is of more important (Canifield, 1989), because not all Fe (III) minerals are equally bioavailable (i.e can be readily reduced by bacterial processes at surface temperature). However, goethite and hematite which are $\mathrm{Fe}$ oxide minerals recorded in this study have been noted to be reducible and react to some extent with sulfide (Canifield, 1989). The Ameki Formation is deposited in a shallow marine shelf setting in which pore- water sulfide concentration is relatively lower than the bioavailable Fe (III) concentration.

\section{PALEOPRODUCTIVITY}

The amount of organic matter produced in per unit area and per unit time is referred to as paleoproductivity (Dong and Wang, 1996). Paleoproductivity proxies include; $\mathrm{P}, \mathrm{Ba}$ and organic carbon or organic matter (Filippelli and Delaney, 1994; Murray and Leinen, 1996; Dymond and Collier, 1996; Chen et al., 1998; Pujol et al., 2006; Paytan and Griffith, 2007; Algeo et al., 2011; Yong et al., 2012). P/Al or P/Ti and Ba/Al or Ba/Ti are also useful proxies for paleoproductivity (Dean et al., 1997; Latimmer and Filippelli, 2002; Algeo et al., 2011). These ratios are preferable proxies than absolute $P$ and Ba because they mitigate the dilution effects of organic matter and authigenic minerals on the absolute $P$ and $\mathrm{Ba}$ contents in terrigenous organic matter (Algeo et al., 2011; Latimmer and Filippelli, 2012). $P$ is a major constituents of skeletal material. Its sources in the world oceans were outlined to include; the composition of atmospheric precipitation and dust, river, underground and glacial run off, abrasion of the shores, volcanic and hydrothermal activities as well as the composition of cosmic materials (Baturin (1982). Ba are formed in oceanic particles as a result of decomposition/uptake in microenvironments and $\mathrm{Al}$ and $\mathrm{Ti}$ are sourced from terrigenous detrital matter (Dymond et al., 1992; Calvert and Pedersen, 1993; Algeo and Maynard, 2004; Yong et al., 2012). The $\mathrm{P} / \mathrm{Al}$ or $\mathrm{P} / \mathrm{Ti}$ and $\mathrm{Ba} / \mathrm{Al}$ or $\mathrm{Ba} / \mathrm{Ti}$ can represent the nutrient conditions and the amount of organisms in the ancient sea respectively (Yong et al., 2012). For the Ameki Formation, the P/Al and P/Ti range from 2.30 to 7.40 and 1.96 to 4.95 respectively. These suggest high paleoproductivity (Ageo et al., 2011; Yong et al., 2012). Ba/Al and $\mathrm{Ba} / \mathrm{Ti}$ values that vary from 647 to 1294 and from 433 to 1100 respectively, also agree with high paleoproductivity (Dean et al., 1997; Yong et al., 2012). These indicate Ameki Sea (shallow marine) to have supported large number of organisms on the water surface above the shelf. This interpretation is in agreement with shallow marinemacro and microfossils such as pelecypods, gastropods, nautiloids, echinoids, radiolarians, remains of whales, foraminifera and ostracodes recovered from the formation by previous workers (e.g. Newton, 1922; Eames, 1957; Berggren, 1960; Adegoke, 1969; Adegoke and Tevesz, 1974; Adegoke et al., 1980; Whiteman, 1982; Arua, 1982, 1988; Arua and Rao, 1987; Fayose and Ola, 1990; Nzekwe and Okoro, 2016). It also supported the interpreted depth ranges of occurrence of the faunal assemblages stated to range from 10-65m (Jones, 1951; Buchanam, 1958) and did not exceed 80 m (Arua, 1988). Studies have related high biologic productivity to phosphorites formed in upwelling systems along coastlines (Brookfield et al., 2009; Dumoulin et al., 2004, 2008, 2011). Dumoulin et al. (2011) employed paleontologic and sedimentologic data as upwelling evidences of phosphorite formation and noted that abundance of radiolarians may be analogous to modern plankton accumulations in high- productivity upwelling zones whereas accumulation of organic- rich shale and multiple beds of granular phosphorites is indicative of a setting with high productivity. Ameki Formation is affected by upwelling oceanic hydrothermal fluid. Arua and Rao (1987) emphasized the influence of Benguela current on the water temperature of the Ameki Sea.

Organic carbon content of the Ameki Formation varies from 0 to $6 \mathrm{wt} \%$. The variation is attributed to redox conditions of deposition. Oxic condition destroys organic matter whereas its preservation is enhanced by a reducing (anoxic) condition (Yong et al., 2012). The organic carbon does not represent the content of the original organic matter in the formation, thus, there is possibility of underestimation of paleoproductivity. In spite of this limitation, high paleoproductivity remains the attribute of the Ameki depositional condition.

Strong upwelling currents, high biological productivity, plankton blooms and large amount of organic matter production and subsequent accumulation trigger phosphate genesis in the shelf margin environment (Brookfield et al., 2009). Other controlling factors include; changes in sea level, rates of sedimentation, depth of impingement of the oxygen- minimum zone on the shelf and slope, concentration of various elements 
and ions and $\mathrm{Eh}, \mathrm{pH}$ and alkalinity of the pore fluids (Robert and Vercoutere, 1986). Marine phosphorites have also been linked to formation under anoxic bottom settings (Ece, 1990; Brookfield et al., 2009). The phosphorites formed may occur as primary phosphorite mud (microphorite), concretions or nodules, microconcretions in muds (pellets in mudstones), and as lenses and layers in encasing sediments (e.g Kennedy and Garrison, 1975; Birch, 1980; Glenn and Arthur, 1988; Föllmi and Garrison, 1991; Glenn et al., 1994).This supported the formation of Ameki Phosphorites under anoxic bottom setting. Ameki phosphorites are dominantly francolites, which have been described as the most abundant authigenic phosphate phase in marine sediments (McConnell, 1973; Jahnke, 1984). Formation of Ameki phosphoritesis explained using the model of Baturin (1982) which consists of biogenic- diagenetic processes of phosphate formation in fine grained sediments and subsequent reworking of the sediments to concentrate the apatite. The Ameki phosphorites is associated with sediments which accumulated beneath the West African coastal upwelling zones during the Eocene and were influenced by warm Benguela Oceanic Current from the Southern Atlantic Ocean. The nutrient- rich waters with phosphorus upwelling in this zone stimulated high primary productivity by phytoplankton and thus supported large number and diversity of species (e.g. pelecypods, gastropods, nautiloids, whales, radiolarians, echinoides, foraminifera, ostracodes etc) in the water surface above the shelf setting. Downward flux of phytodetritus was likely situation, and accumulation of much in the sediments due to high organic flux, high biological oxygen demand, as well as short sinking transit time on the shallow shelf (Crosby and Bailey, 2012). The calcareous parts/exoskeleton of the organisms which were abundant and diverse sourced the calcium carbonate (Birch, 1990). This is evidenced from the high concentration of $\mathrm{Ca}$ in the phosphorites. Body tissues of the organisms when dead, with time decayed gradually after burial i.e the microbial processes that mediate phosphorus cycling by creating sinks for the marine phosphorus acted upon the dead tissues of the organisms buried in the sediments (Schulz and Schulz, 2005; Aming et al., 2008, 2009; Goldhammer et al., 2010) and thus, led to phosphate pumping into the pore- waters of the sediments. Super saturation of the pore water with respect to apatite resulted in the precipitation of the phosphate. Brookfield et al. (2009) noted an increase in dissolved phosphate level under anoxic conditions and microbial activity. Phosphorite nodules thus, formed within the sediments by diagenetic reactions between the organic- rich sediments and their phosphate- enriched pore- waters. The low carbonate substitution by phosphate recorded by the phosphorites suggest minimal re-working typical of early stage of diagenesis. Eocene sea level fluctuations controlled the phosphate formation and reworking (Baturin, 1971; Glenn and Arthur, 1988, 1990; Grimm, 1992).

\section{CONCLUSION}

The geochemistry of the phosphorites of the Ameki Formation reveals that most of the phosphorites are francolites and have similar in composition to the phosphorites of South West African and Midcontinent, USA, except for minor variations. The variation in abundance of the elements and oxides is attributed to varying degrees of dilution from non phosphatic components. The Ameki phosphorite is interpreted to form in a shallow marine (shelf) setting. Paleoenvironment is characterized by high biologic productivity at the water surface and relatively higher reducible $\mathrm{Fe}$ (III) and lower sulfur concentrations in the pore- water. Upwelling by Benguela Current along West African Coast and sediment re- working were the possible mechanisms of formation and concentration of the phosphorites. Transgression and regression played a vital role.

\section{REFERENCES}

Adegoke, O. S., 1969. Eocene stratigraphy of southern Nigeria. Coll. L' Eocene 111. Mem. Bur. Rech. Geol. Min. 69, 23- 48

Adegoke, O. S., Tavesz, M. J. S., 1974. Gastropod predation patterns in the Eocene of Nigeria. Lethaia $7(1), 18-23$

Adegoke, O. S., Arua, I., Oyegoke, O., 1980.Two new nautiloids from Imo Shale (Paleocene) and Ameki Formation (Middle Eocene), Anambra State, Nigeria. Journal of Mining and Geology 17, 85- 89

Algeo, T. J., 2004. Can marine anoxic events drew down the trace element inventory of seawater? Geology 32(12): 1057-1060 doi: $10.1130 / G 2089.1$

Algeo, T. J. and Magnard, J. B., 2004. Trace element behavior and redox facies analysis of core shales of upper Pennsylvennian Kansas- type cyclotherms. Chemical Geology 206: 289- 318.

Algeo, T. J., Kuwahara, K., Sano, H., et al., 2011. Spatial variation in sediment fluxes, redox conditions, and productivity in the PermianTriassic Panthalassic Ocean. Palaeogeography, Palaeoclimatology, Palaeoecology 308: 65- 83.

Ames, L. L., Jr., 1959. The genesis of carbonate apatite: Economic Geology 54(5); 829- 841.

Arning, E. T., Birgel, D., Schulz- Vogt, H. N., Holmkvist, L., Jørgensen, B. B., Larsson, A., Peckmann, J., 2008. Lipid biomarker patterns of phosphogenic sediments from upwelling regions. Geomicrobiology Journal 25(2), 69- 82.

Arning, E. T., Birgel, D., Brunner, B., Peckmann, J., 2009. Bacterial formation of phosphaticlaminites off Peru. Geobiology 7(3), 295- 307. 
Arua, I, 1982. Borings and shell damage in Eocene gastropoda, southeastern Nigeria. Paleogeography, Paleoclimatology, Paleoecology 38 (3- 4), 269- 282.

Arua, I., 1988. Paleoecology of the Eocene Ameki Formation of southeastern Nigeria. Journal of African Earth Sciences 7(7- 8): 925- 932, doi: 10.1016/0899- 5362(88) 90007-3.

Arua, I., Rao, V. R., 1987. New stratigraphic data on the Eocene Ameki Formation, southeastern Nigeria. Journal of African Earth Scinces 6(4), 391- 397.

Baturin, G. N., 1971. The stages of phosphorite formation on the ocean floor: Nature, Physical Science 232(29), 61- 62

Baturin, G. N., 1982. Phosphorites on the sea floor: Origin, composition and distribution. Elsevier, Amsterdam, 343p.

Baturin, G. N., Bezrukov, P. L., 1979. Phosphorites on the sea floor and their origin. Marine Geology 31(3- 4), 317- 332

Baturin, G. N., Merkolova, K., Chalov, P., 1972. Radiometric evidence of recent formation of phosphatic nodule in marine shelf sediments. Marine Geology 13(3), 37- 41.

Benkhelil, J., 1982. Benue Trough and Benue Chain. Geology Magazine 119(2), 155- 168

Benkhelil, J., 1989. The origin and evolution of the Cretaceous Benue Trough (Nigeria). Journal of African Earth Sciences 8(2), 251- 282.

Benmore, M. L., Coleman, M. L., McArthur, 1983. Origin of sedimentary francolite from its sulphur and carbonate isotope composition. Nature 302, 516- 518

Berggren, W. A., 1960. Paleocene biostratigraphy and planktonic foraminifera of Nigeria (W. Africa). Proceedings $21^{\text {st }}$ intern'l Geol. Congress, Copenhagen. 6, 41- 55.

Birch, G. F., 1980. A model of penecontemporaneous phosphatization by diagenetic and authigenetic mechanisms from the Western margin of southern Africa. In: Y.K. Bentor (Ed.), Marine phosphorite- Geochemistry, Occurrence, Genesis. Society for Sedimentary Geology Special Publication 29, Tulsa,79- 100.

Birch, G. F., 1990. Posphorite deposits on South African continental margin and coastal terrace. In: Burnett, W.C., and Riggs, S. R. (Eds.), phosphate deposits of the world: vol. 3, Genesis of Neogene to Recent phosphorites. Cambridge University Press, Cambridge, 153- 156.

Boggs, S., 2006. Principles of sedimentology and Stratigraphy ( $4^{\text {th }}$ edition), Pearson Prentice Hall, Upper Saddle River, N. J, 662p.,
Brookfield, M. E., Hemmings, D. P., and Straaten, P. Van, 2009. Paleoenvironment and origin of the sedimentary phosphorites of the Napo Formation (Late Cretaceous, Oriente Basin, Ecuador). Journal of South American Earth Sciences 28(2), 180- 192.

Buchanam, J. B., 1958. The bottom faunal communities across the continental shelf off Acra, Ghana (Gold Coast). Journal of Zoology 130(1), 1- 56.

Burke, K. C. B., 1972. Longshore drift, sub- marine canyon and submarine fans in the development of Niger Delta, AAPG Bulletin 56(10), 1975- 1983.

Burke, K. C., Dessauvagie, T. F. J., Whiteman, A. J., 1972. Geological history of the Valley and its adjacent areas. In: Dessauvagie, T. F. J. and Whiteman, A. J., (Eds.), African Geology. University of Ibadan Press, pp. 187- 205

Burnett, W. C., 1977. Geochemistry and origin of phosphorite deposits from off Peru and Chile. Geology Society of American Bulletin 88(6), 813- 823

Burnett, W. C., Veeh, H. H., Soutar, A., 1980. U- series, oceanographic and sedimentary evidence in support of recent formation of phosphate nodules off Peru. In: Bentor, Y.K. (Ed.), Marine phosphorites. Society of Economic Paleonologist and Mineralogist Special Publication 29, 61- 72.

Calvert, S. E. and Pedersen, T. F., 1993. Geochemistry of recent oic and anoxic marine sediments: Implications for the geological record. Marine Geology 113: 67- 68.

Canifield, D. E., 1989. Reactive iron in marine sediments. Geochimica et Cosmochimica Acta 53(3): 619- 632.

Chen, S. Y., Ambe, S., Takematsu, N. and Ambe, F., 1996. The chemical states of iron in marine sediments by means of Mössbauer Spectroscopy in combination with chemical leachings. Journal of Oceanography 52: 705715

Cook, P. J., 1976. Sedimentary phosphate deposits. In: Hand Book of strata- bound and stratiform ore deposit part III. Regional studies and specific deposits vol. 7. Elsevier, New York, 505- 535

Cronan, D. S., 1980. Underwater Minerals. Academic Press, London 363p.

Crosby, C. H., Bailey, J. V., 2012. The role of microbes in the formation of modern and ancient phosphatic mineral deposits. Frontier in Microbiology 3, 241- 246.

Dar, S. A., and Khan, K. F., 2016. Depositional environment of phosphorites of the Sonrai 
Basin, Lalitpur District, Uttar Pradesh, India Applied Studies of Coastal and Marine Environments, Maged Margharny, IntechOpen, doi: $10.5772 / 62186$.

Dean, W. E., Gardener, J. V., and Piper, D. Z., 1997. Inorganic geochemical indicators of glacialinterglacial changes in productivity and anoxia on the California continental margin. Geochim. Cosmochim. Acta 61: 4507- 4518.

Dingle, R. V., 1975. Agulhas Bank phosphorites: a review of 100 years of investigation. Transactions of the Geological Society of South Africa 77, 261- 264.

Dumoulin, J. A., Harris, A. G., Blome, C. D., and Young, L. E., 2004. Depositional settings, correlation, and age of Carboniferous rocks in the western Brooks Range, Alaska. Economic Geology, 99: 1355- 1384

Dumoulin, J. A., Whalen, M. T., and Harris, A. G., 2008. Lithofacies, age and sequence stratigraphy of the Carboniferous Lisburne Group in the Skimo Creek area, Central Brooks Range. In: Haeussler, P.J. and Galloway, J. P. (Eds.), Studies by the US Geological Survey. Professional Paper 1739- B, 64p.

Dumoulin, J. A., Slack, J. F., Whalen, M. T., and Harris, A. G., 2011. Depositional setting and geochemistry of phosphorites and metalliferous black shales in the Carboniferous- Permian Lisburne Group, Northern Alaska. US Geological Survey, Reston, Virginia 64p.

Dymond, J. and Collier, R., 1996. Particulate barium fluxes and their relationships to biological productivity. Deep- Sea Research 43: 12831308.

Dymond, J., Suess, E. and Lyle, M., 1992. Barium in deep sea sediments: a geochemical proxy for paleoproductivity: Paleoceanography 7: 163191.

Eames, F. E., 1957. Eocene mollusca from Nigeria: A revision. Bulletin of the British Museum (Natural History) 3(2),23- 70

Ece, O. I., 1990. Geochemistry and occurrence of authigenetic phosphate nodules from the Desmoinesian cyclic Excello epeiric sea of the Midcontinent, USA. Marine and Petroleum Geology 7(3), 298- 312, doi: 10.1016/02648172(90)90007-4

Fairhead, J. D., 1988. Mesozoic plate tectonic reconstruction of the central South Atlantic Ocean: the role of the West and Central African Rift Systems, Tectonophysics155 (1- 4), 181191, doi: 10.1016/004-1951(88)90165-x.

Fayose, E. A., and Ola, P.S., 1990. Radiolarian occurrencies in the Ameke type section, eastern
Nigeria. Journal of Mining and Geology 26, 7580.

Filipelli, G. M., 2011. Phosphate rock formation and marine phosphorus geochemistry: the deep time perspective. Chemosphere 84(6), 759- 766, doi: 10.1016/j.chemosphere.2011.02.019.

Filippelli, G. M. and Delaney, M. L., 1994. The oceanic phosphorus cycle and continental weathering during the Neogene. Palaeogeography, Palaeoclimatology, Palaeoecology 9: 643- 652.

Föllmi, K. B., 1996. The phosphorus cycle, phosphogenesis and marine phosphate- rich deposits, Earth Science Reviews 40(1-2), 55124, doi: 10.1016/0012-8252(95)00049-6.

Föllmi, K. B., Garrison, R. E., 1991. Phosphatic sediments, ordinary or extraordinary deposits? The example of the Miocene Monterey Formation (California). In: Muller, D.W., Mckenzie, J. A., Weissert, H(Eds.), Controversies in modern Geology, Academic Press, London pp. 55- 84.

Galfati, I., Sassi, A. B., Zaïer, A., Bouchardon, J. L., Bilal, E., Joron, J. L. and Sassi, S., 2010. Geochemistry and mineralogy of PaleoceneEocene Oum El Khecheb phosphorites (GafsaMetlaoui Basin) Tunisia. Geochemical Journal, 44: 189- 210.

Garnit, H., Salah, B. and Ian, J., 2017. Geochemistry and depositional environments of paleoceneEocene phosphorites: Metlaoui Group, Tunisia. Journal of African Earth Sciences, 134: 704736.

Glenn, C. R., Arthur, M. A., 1988. Petrology and major elemental geochemistry of Peru Margin phosphorites and associated diagenetic minerals: authigenesis in modern organic rich sediments. Marine Geology 80 (3- 4), 231- 267, doi: 10.1016/0025-3227(88)90092-8.

Glenn, C. R., Arthur, M. A., 1990. Anatomy and origin of a Cretaceous phosphorite- greensand giant, Egypt. Sedimentology 37: 123- 154.

Glenn, C. R., Föllmi, K. B., Riggs, S. R., Baturin, G. N., Grimm, K. A., Trappe, J., Abed, A. M., Galli- Olivier, C., Garrison, R. E., Ilyin, A. V., Jehl, C., Rohrlich, V., Sadaqah, R. M. Y., Schidlowski, M., Sheldon, R., Siegmund, H., 1994. Phosphorus and phosphorites: sedimentology and environments of formation. Eclogae Geologicae Helvetiae, 87(3), 747- 788.

Goldhammer, T., Brüchert, V., Ferdelman, T.G., Zabel, M., 2010. Microbial sequestration of phosphorites in anoxic upwelling sediments. Nature Geoscience 3,557- 561. 
Grimm, K. A., 1992. The sedimentology of coastal upwelling systems. University of California Santa Cruz Ph.D, dissertation.

Gruner, By J. W., McConnell, D., and Armstrong, W. D., 1937. The relationship between crystal structure and chemical composition of Enamel and Dentin. Journal of Biological Chemistry 121, 771- 781.

Hatch, J. R., and Leventhal, J. S., 1992. Relationship between inferred redox potential of the depositional environment and geochemistry of the upper Pennsylvannian (Missourian) stark shale member of the Dennis Limestone, Wabaunsco country, Kansas, USA. Chemical Geology 99: 65- 82.

Hoque, M., Nwajide, C. S., 1984. Tectonosedimentological evolution of an elongate intracratonic basin (aulacogen): the case of the Benue Trough of Nigeria. Journal of Mining and Geology 21, 19- 26.

Jahnke, R. A., 1984. The synthesis and solubility of carbonate fluorapatite. American Journal of Science 284, 58- 78

Jones, N. S., 1951. The bottom fauna off the south of the isle of Man. Journal of Animal Ecology 20(1), 132- 144, doi: 10.2307/1651.

Jones, B. and Manning, D.A.C., 1994. Comparison of geochemical indices used for the interpretation of paleoredox conditions in ancient mudstones. Chemical Geology 111: 111- 129.

Kennedy, W. J., Garrison, R. E., 1975.Morphology and genesis of nodular phosphates in the Cenomanian glauconite marl of south east England. Lethaia, 8(4), 339- 360.

Khan, K. F., Khan, S. A., Dar, S. A., and Husain, Z., 2012. Geochemistry of phosphorite deposits around Hirapur Mardeora area in Chhatarpur and Sagar Districts, Madhya Pradesh, India. Journal of Geology and Mining Research, 4(3): 51- 64 .

Kolodny, Y., 1980. The origin of phosphorite deposits in the light of occurrences of recent seafloor phosphorites. Society of Economic Paleontologists and Mineralogists Special Publication 29, 249.

Latimmer, J. C. and Filippelli, G. M., 2002. Eocene to Miocene terrigenous inputs and export production: Geochemical evidence from ODP Leg 177, Site 1090. Palaeogeography, Palaeoclimatology, Palaeoecology 182(3- 4): 151- 164

Li, Y. F., Zhan, J. C., Zhan, J. P., Wei, .J., Hu, X.L., Zeng, W. T. and Fu, W., 2015. Geochemical changes in the early Cambrian interval of the Yangtze Platform, South China: Implications for hydrothermal influence and paleoceano redox condition. Journal of Asian Earth Sciences 109: 100- 123

Lysons, T. W. and Severman, S., 2006. A critical look at iron paleoredox proxies: New insights from modern euxinic marine basins. Geochim. Cosmochim. Acta 70: 5698- 5722.

Lysons, T. W., Werne, J. P., Hollander, D. J. and Murray, R. W., 2003. Contrasting sulfur geochemistry and $\mathrm{Fe} / \mathrm{Al}$ and $\mathrm{Mo} / \mathrm{Al}$ ratios across the last oxic to anoxic transition in the Cariaco Basin, Venezuela. Chemical Geology 195: 131157.

Maron, P., 1969.Stratigraphical aspects of the Niger Delta. Journal of Mining and Geology 4 (1 \&2), 3- 12.

McClellan, G. H., 1980. Mineralogy of carbonate fluorapatites. Journal of Geological Society of London 137(6), 675- 681, doi: 10.1144/gsjgs.137.6.0675.

McConnell, D., 1973. Apatite, its crystal chemistry, mineralogy, utilization and geologic and biologic occurrences. Springer- Verlag, Berlin, 111p.

Morford, J. I. and Emerson, S., 1999. The geochemistry of redox sensitive trace metals in sediments. Geochim. Cosmochim. Acta 63: 1773-1750.

Murat, R. C., 1972. Stratigraphy and paleogeography of the Cretaceous and Lower Tertiary in southern Nigeria. In: A. J. Whiteman (Ed.), African Geology, University of Ibadan press, Nigeria, pp. 251- 266.

Murray, R. W. and Leinen, M., 1996. Scavanged excess aluminum and its relationship to bulk titanium in biogenic sediment from the Centram equatorial Pacific Ocean. Geochim. Cosmochim. Acta 60: 3869- 3878.

Nameroff, T. J., Calvert, S. E. and Murray, J. W., 2004. Glacial- interglacial variability in the eastern tropical North Pacific oxygen minimum zone recorded by redox- sensitive trace metals. Palaeoceanography 19, PA1010 doi: 10.1029/2003PA000912.

Nathan, Y., 1984. The Mineralogy and geochemistry of phosphorites. In: Nriagu, J.O. and Moore, P.B. (Eds.), Phosphate Minerals. Springer- Verlag, Berlin, 275- 291.

Neubert, N., Năgler, T. F., and Bottener, M.E., 2008. Sulphidity controls molybdenum isotope fractionation into euxinic sediments: Evidence from the modern Black Sea. Geology 36: 775778 doi: $10.1130 / G 24959 A .1$

Newton, R. B., 1922. Eocene molluscan from Nigeria. Geological Survey of Nigeria Bulletin 3, 115 
Nichols, G., 2009. Sedimentology and Stratigraphy, $2^{\text {nd }}$ Wiley- Blackwell, UK.

Nwajide, C. S., 2013. Geology of Nigeria's Sedimentary Basins. CSS Press, Lagos, 548p.

Nzekwe, I. E. and Okoro, A.U., 2016. Organic and trace element geochemistry of the Ameki Formation, southeastern Nigeria: Implications and hydrocarbon generating potential. Journal of Applied Geology and Geophysics 4(4): 12- 20.

Parker, R. J., 1971. The petrography and major element geochemistry of phosphorite nodule deposits on the Agullas Bank, South Africa. Program Bulletin of South African National Oceanographic Research and Marine Geology 2, 94.

Parker, R. J., Siesser, W. G., 1972. Petrology and origin of some phosphorites from the South African continental margin. Journal of SedimentaryPetrology 42(2), 434- 440.

Parker, R. J., Andsreisser, W. G., 1972. Petrology and origin of some phosphorites from the south Africa continental margin. Journal of Sedimentary Petrology 42, 434- 440.

Pattan, J. N. and Pearce, N. J. G., 2009. Bottom wateroxygenation history in southern Arabian Sea during the past 140ka: Results from redoxsensitive elements. Palaeogeography, Palaeoclimatology, Palaeoecology 280: 396405.

Pujol, F., Berner, Z. and Stüben, D., 2006. Paleoenvironmental changes at the Frasnian/Farnennian boundary in key European sections: Chemostratigraphic constraints. Paleogeography, Paleoclimatology, Paleoecology 240: 120- 145.

Pytan, A. and Griffith, E. M., 2007. Marine barite: Recorder of variations in ocean export productivity. Deep- Sea Research II 54: 687705.

Reyment, R. A., 1965. Aspects of the Geology of Nigeria: the stratigraphy of the Cretaceous and Cenozoic deposits. Ibadan University Press, $145 p$.

Rimmer, S. M., 2004. Geochemical paleoredox indicators in Devonian Mississippian black shales, central Appalachian Basin (U.S.A). Chemical Geology 206: 373- 391.

Rimmer, S.M., Thompson, J. A., Goodnight, S. A., and Robl, T. L., 2004. Multiple controls on the preservation of organic matter in DevonianMississippian marine black shales: geochemical and petrographic evidence. Plalaeogeography, Palaeoclimatology, Palaeoecology 215: 125154.
Robert, A. E., Vercoutere, T.L., 1986. Geology and geochemistry of the upper Miocene phosphate deposit near New Guyama, Santa Barbara Country, California. US Geological Survey Bulletin 1635: 23- 27.

Schieber, J., 2009. Discovery of agglutinated benthic foraminifera in Devonian black shales and their relevance for the redox state of the ancient seas. Palaeogeography, Palaeoclimatology, Palaeoecology 271: 292-300.

Schulz, H. N., Schulz, H. D., 2005. Large sulfur bacteria and the formation of phosphorites. Science 307(5708), 416- 418.

Scott, C., and Lysons, T. W., 2012. Contrasting molybdenum cycling and isotopic properties on euxinic versus non- euxinic sediment and sedimentary rocks: Re- fining the paleoproxies. Chemical Geology 324- 325: 19- 27.

Sheldon, R. P., 1981. Ancient marine phosphorites. Annual Review of Earth planet Science 9, 251284.

Short, K. C., Stauble, A.J., 1967. Outline of geology of Niger Delta. AAPG Bulletin 51, 761- 779.

Simpson, D. R., 1964. The nature of the alkali carbonate apatites. Amr Min. 49, 363- 376.

Trappe, J., 1998. Phanerozoic phosphorite depositional system: A dynamic model for a sedimentary resource system. Springer, Berlin, New York doi: 10.1016/0012-8252(95)00049-6.

Tribovillard, N., Algeo, T. J., Lysons, T., and Riboulleau, A., 2006. Trace metals as paleoredox and paleoproductivity proxies: An update. Chemical Geology 232: 12- 32.

Veeh, H. H., Burnett, W. C., Soutar, A., 1973. Contemporary phosphorites on the continental margin of Peru. Science 181(4102), 844- 845, doi: 10.1126/science.181.4102.844.

Vine, J. D. and Tourtelot, E. B., 1970. Geochemistry of black shale deposits: A summary report. Economic Geology 65: 25- 27.

White, E. I., 1926. Eocene fishes of Nigeria. Bulletin of Geological Survey ofNigeria 10, 78.

Whiteman, A. J., 1982.Nigeria: Its Petroleum Geology, Resources and Potential. Graham and Trotman, London, 394p.

Wignall, P. B., Zonneveld, J. P., Newton, R. J., Amor, K., Sephton, M. A., and Hartley, S., 2007. The endTriassic mass extinction record of Williston Lake, British Columbia. Palaeogeographic, Palaeoclimatology, Palaeoecology 253: 385406. 
14 ONUIGBO, EVANGELINE NJIDEKA, OKORO, ANTHONY UWAOMA AND CHIBUZOR, STELLA 'NWAIFE'

Yao, C., Guo, W., Liu, J. and Li, H., 2017. Multiple proxies on the paleoenvironment of the early Cambrian marine black rock series in the Terim Basin, NW China: Molybdenum isotope and trace element evidence. International Journal of Geosciences 8: 965- 983.

Yong, L.Q., Ning, Z.N., Lei, Z., Nian, W.Y., Jing, Q., Lin, Q., Yi, Z. and Yong, M., 2012. Correlation of burial organic carbon and paleoproductivity in

the Mesoproterozoic

Hongshuizhuang

Formation, northern North China. Chinese

Science Bulletin 58(11): 1299- 1309 doi: 10.1007/s11434-012-5534-2.

Zhou, L., Wignall, P.B., Su, J., Feng, Q.L., Xie, S.C., Zhao, L.S. and Huang, J.H., 2012. U/Mo ratio and $\delta^{98 / 95}$ Mo as local and global redox proxies during mass extinction events. Chemical Geology 324- 325: 99- 107. 